\title{
Eksistensi Pencipta Lagu Setelah Peraturan Pemerintah Nomor 56 Tahun 2021 Disahkan
}

\author{
Sri Wahyuni Muhtar ${ }^{1}$, Faisal Faisal ${ }^{2}$ \\ ${ }^{1,2}$ Universitas Negeri Makassar, Makassar, Indonesia \\ Email: sriwahyuni@unm.ac.id
}

\begin{abstract}
Based on the phenomenon of the endorsement of PP Number 56 of 2021, formulated research questions, namely how the songwriter responds after the rule is passed, and what impact the rule has on the existence of the songwriter. This research aims to find out the response and impact of PP No.56 of 2021 for songwriters, as well as help the government in the socialization of the rules. The research method used is qualitative with data reduction procedures, data classification, data presentation, conclusion withdrawal and verification of data from data collection results through interviews, participant observations and documentation. The results showed that the positive response of songwriters after PP Number 56 of 2021 was passed through selfregistration and work in LMK creator rights, as well as registering works online at DJKI Kemenkumham. But there are also songwriters who have not responded to registering works institutionally because of concerns that creation will be consumed on a limited basis so as to provide publication losses for creators. Furthermore, the impact of these rules on the existence of songwriters is to make creators more productive to produce works periodically, the creation of works becomes more quality and quality in the world of the music industry, and the right to publish songwriters exist in the community and exist on the side that utilizes national and international works.
\end{abstract}

Keywords: Existence, Songwriter, PP No. 56 Of 2021.

Abstrak: Berdasarkan fenomena pengesahan PP Nomor 56 tahun 2021, dirumuskan pertanyaan penelitian yaitu bagaimana respons pencipta lagu setelah aturan tersebut disahkan, serta apa dampak aturan tersebut terhadap eksistensi pencipta lagu. Penelitian ini bertujuan untuk mengetahui respons dan dampak PP No. 56 tahun 2021 bagi pencipta lagu, serta membantu pemerintah dalam sosialisasi aturan tersebut. Metode penelitian yang digunakan adalah kualitatif dengan prosedur mereduksi data, klasifikasi data, penyajian data, penarikan kesimpulan dan verifikasi data dari hasil pengumpulan data melalui wawancara, observasi partisipan, dan dokumentasi. Hasil penelitian menunjukkan bahwa respons secara positif pencipta lagu setelah PP Nomor 56 tahun 2021 disahkan melalui pendaftaran diri dan karya di LMK hak pencipta, serta mendaftarkan karya secara online di DJKI Kemenkumham. Namun ada juga pencipta lagu yang belum memberi respons mendaftarkan karya secara kelembagaan karena kekhawatiran ciptaan akan dikonsumsi secara terbatas sehingga memberikan kerugian publikasi bagi pencipta. Selanjutnya, dampak aturan tersebut terhadap eksistensi pencipta lagu yaitu membuat pencipta lebih produktif menghasilkan karya secara berkala, pembuatan karya menjadi lebih berkualitas dan bermutu di dunia industri musik, serta hak publikasi pencipta lagu eksis di masyarakat dan eksis di pihak yang memanfaatkan karya berskala nasional dan internasional.

Kata Kunci: Eksistensi, Pencipta Lagu, PP No.56 tahun 2021

\section{Article info:}

Received: 05 Oktober 2021

Reviewed: 17 November 2021

Accepted: 27 November 2021

\section{PENDAHULUAN}

Tanggal 30 Maret 2021 Presiden Republik Indonesia telah mengesahkan Peraturan Pemerintah Nomor 56 Tahun 2021 tentang pengelolaan royalti hak cipta lagu. Hal tersebut dilakukan sebagai perlindungan hukum bagi pencipta lagu, jika dikaji dari aturan sebelumnya telah terbit juga Undang-Undang No. 28 Tahun 2014 tentang Hak Cipta. PP No. 56 tahun 2021 disahkan untuk mempertegas kembali UU No.28 tahun 2014 tersebut.

PP No. 56 tahun 2021 mengatur banyak hal terkait siapa saja yang berhak mendapatkan royalti, tata cara pengelolaan royalti, pendistribusian royalti hingga lembaga yang disebutkan sebagai pengelola royalti dari para pengguna karya musik. Disebutkan pada pasal 1 ayat 5 , pencipta adalah seseorang atau beberapa 
orang yang secara sendiri atau bersama-sama menghasilkan suatu ciptaan karya musik yang bersifat khas dan pribadi. Disebutkan juga pada ayat selanjutnya, bahwa yang termasuk pemegang hak cipta yang dapat menerima royalti adalah selain pencipta sebagai pemilik Hak Cipta, juga ada pihak yang menerima hak tersebut secara sah dari Pencipta, atau pihak lain yang menerima lebih lanjut hak dari pihak yang menerima hak tersebut secara sah.

Pengesahan PP Nomor 56 tahun 2021 dilakukan pada masa pandemi dimana menurut (Somawati et al., 2020) dampak pandemi pada seni suara yaitu munculnya ide baru dan kontemporer dalam penciptaan karya lagu dalam berbagai genre tentang Covid-19 atau tentang keluhan masyarakat terkait keadaan ekonomi yang sulit. Pencipta lagu dan penyanyi berusaha tetap eksis melalui berbagai media sosial seolah ingin meringankan beban psikologis masyarakat di tengah pandemi atau mengungkapkan isi hati yang sulit akibat Covid-19.

Pencipta lagu dan pelaku seni musik lainnya memiliki strategi masing-masing untuk mempertahankan eksistensinya, dikutip dari penelitian sebelumnya terkait eksistensi suatu penyaji musik (Ikram, 2020) untuk mempertahankan eksistensi penyaji musik dengan mengadakan riset pasar, membuat konten berkala hingga melakukan kolaborasi bersama pelaku musik lainnya. Perlindungan Pemerintah yang diberikan dalam bentuk payung hukum memberi ruang bagi para pencipta lagu agar tetap eksis tanpa harus khawatir terkait hak ekonomi dan hak moralnya. Payung hukum tersebut salah satunya adalah PP No. 56 tahun 2021 yang perlu dipahami oleh para pencipta lagu dan hak terkait agar mendapatkan hak ekonominya berupa royalti dari pengguna musik yang bersifat komersil.

Respons pada hakikatnya merupakan sikap yang menjadi tingkah laku balik dan merupakan proses pengorganisasian rangsang dimana suatu rangsangan diorganisasikan sedemikian rupa sehingga menjadi representasi fenomenal (Adi, 2013). Penelitian ini kemudian bertujuan untuk mengetahui respons dan dampak PP No. 56 tahun 2021 bagi pencipta lagu, serta membantu pemerintah dalam sosialisasi aturan tersebut. Berdasarkan hal tersebut maka rumusan masalah penelitian ini adalah: (1) Bagaimana respons pencipta lagu setelah PP Nomor 56 tahun 2021 disahkan?; (2) Apa dampak PP Nomor 56 tahun 2021 terhadap eksistensi pencipta lagu?

\section{METODE}

Metode penelitian yang digunakan pada penelitian ini adalah kualitatif, menurut (Sugiyono, 2013) karakteristik kualitatif bersifat deskriptif, data yang terkumpul dalam bentuk kata-kata dan dianalisis secara induktif. Data yang dikumpulkan dari berbagai sumber seperti tulisan ilmiah, narasumber, dan peneliti sendiri terlibat sebagai instrumen penelitian. Hasil dari berbagai sumber tersebut dideskripsikan selama dan setelah dari lapangan penelitian.

Prosedur pelaksanaan penelitian dilakukan dalam beberapa tahapan yaitu reduksi data, klasifikasi data, penyajian data, penarikan kesimpulan dan verifikasi data. Hal tersebut juga diungkapkan oleh Strauss dalam (Muhtar, 2021). Reduksi data tulisan catatan lapangan hasil observasi penulis sebagai pencipta lagu dan pengalaman di LMK WAMI dan PAPPRI, klasifikasi dari data hasil wawancara pencipta lagu secara daring sesuai tujuan penelitian, penyajian data sesuai rumusan masalah, serta penarikan kesimpulan dan verifikasi dilakukan secara sejajar.

Pengamatan yang dilakukan Lofland dalam (Hasanah, 2017) menunjukkan peneliti terlibat dalam pengumpulan informasi dan menghasilkan data secara bervariasi. Tim penelitian ini juga terlibat langsung dalam pengumpulan informasi yang dilakukan menggunakan teknik observasi partisipan, wawancara dan dokumentasi video dan tulisan.

\section{HASIL DAN PEMBAHASAN}

\section{Hasil}

\section{Respons pencipta lagu setelah PP No.56 tahun 2021 disahkan}

Sesuai UU nomor 28 tahun 2014 tentang hak cipta pada pasal 87 ayat 1 untuk mendapatkan royalti maka pencipta lagu dapat bergabung dalam LMK pencipta. Tentu harus dibedakan LMK (Lembaga Manajemen Kolektif) untuk pencipta dengan hak terkait. Penelitian ini fokus pada pencipta lagu yang termasuk dalam kategori pemegang hak cipta, pemegang hak cipta adalah pencipta sebagai pemilik hak cipta serta pihak yang menerima hak dari pencipta atau pihak lain yang menerima hak dari pencipta secara sah. Pencipta dapat terdiri dari perseorang maupun kelompok dalam kepemilikan hak suatu karya cipta lagu. LMK pencipta adalah KCI (Karya Cipta Indonesia), 
WAMI (Wahana Musik Indonesia), dan RAI (Perkumpulan Royalti Anugerah Indonesia).

Respons pencipta lagu setelah PP No. 56 tahun 2021 disahkan adalah mendaftarkan diri ke LMK pencipta melalui KCI, WAMI atau RAI. Dari hasil observasi tim peneliti saat ingin bergabung di salah satu LMK pencipta yaitu Wahana Musik Indonesia, cara gabung menjadi anggota WAMI yaitu melakukan pendaftaran secara online pada laman https://www.wami.id, selanjutnya klik bagian membership. Setelah sign up calon anggota memilih sebagai pencipta lagu dan mengisi formulir yang tersedia, aktivasi akun akan dilanjutkan pada email yang didaftarkan. Calon anggota yang berhak bergabung sebagai anggota WAMI adalah pencipta lagu, ahli waris pencipta lagu yang tidak bergabung dalam CMO lainnya serta memiliki minimal satu lagu yang sudah terpublikasi. Calon anggota juga perlu mempersiapkan data link Sportify dan ISCR.

Calon anggota LMK WAMI juga harus melengkapi berkas pendaftaran seperti surat kuasa bermaterai, fotokopi KTP dan NPWP, daftar lagu yang ingin didaftarkan untuk mendapatkan royalti, pas foto hingga surat keterangan dari publisher. Berkas tersebut secara fisik dikirim ke alamat kantor WAMI di Jakarta, calon anggota WAMI juga akan mendapatkan notifikasi melalui email mengenai progres pendaftaran yang telah dilakukan. Setelah melengkapi semua persyaratan pendaftaran maka pencipta lagu sudah berhasil bergabung di LMK WAMI. WAMI akan mengelola dan mendistribusikan hak royalti ke rekening yang telah didaftarkan sesuai data pemanfaatan karya musik secara komersil.

Royalti performing right berhak didapatkan saat karya ciptaan dipublikasi dan diizinkan diputar/ ditampilkan/ disiarkan atau diperdengarkan di tempat umum secara komersil. Performing right yang dimaksud berhak menerima royalti adalah pencipta lirik, pencipta lagu, pencipta musik dan instrumen arranger. Pemilik hak cipta merespons positif PP No. 56 tahun 2021 karena dapat melindungi hak ekonomi di masa pandemi yang kesulitan mengadakan konser secara luring. Anang Hermansyah selaku artis penyanyi dan pencipta lagu saat live on Instagram DJKI Kemenkumham tanggal 9 April 2021 menyatakan respons positif terhadap pengesahan PP No. 56 tahun 2021, hal tersebut merupakan momentum yang ditunggu dan telah diperjuangkan oleh para pencipta lagu. Disahkannya aturan tersebut telah menjamin secara hukum hak-hak yang seharusnya diterima oleh pencipta lagu.

Respons selanjutnya adalah pencipta lagu sadar akan perlindungan hukum menjadi penting untuk mendaftarkan karya ciptaan secara sah di E-hak cipta pada laman website DJKI Kemenkunham yaitu e-hakcipta.dgip.go.id. Catatan karya lagu diperlukan untuk menghindari pembajakan ilegal dan dapat dipertanggung jawabkan secara hukum. Prosedur pendaftaran yaitu melakukan sign up dan aktivasi akun melalui email yang telah didaftarkan pada laman DGIP, selanjutnya melakukan log in untuk melengkapi data diri dan karya cipta yang ingin dilindungi beserta melengkapi kebutuhan dokumen lainnya. Pada tahap berikutnya pencipta akan mendapatkan kode billing yang akan dibayar melalui ATM atau M-Banking, hanya perlu sehari kerja maka pencipta akan menerima sertifikat hak cipta online.

Respons pencipta lagu tidak semua positif karena merasa PP No.56 tahun 2021 tidak akan banyak membantu pencipta lagu. Ada juga pencipta lagu secara sengaja memilih tidak bergabung dalam LMK agar karya ciptaannya dapat diperdengarkan secara gratis. Menjadi kekhawatiran tersendiri bagi pencipta lagu karena berbayarnya karya mereka maka akan mengurangi frekuensi pemutaran/ pertunjukan menggunakan karya mereka. Hal tersebut akan menyebabkan karya menjadi terbatas untuk diakses oleh masyarakat dan memberikan kerugian bagi pencipta lagu jika karya mereka tidak terpakai di masyarakat luas.

\section{Dampak PP No. 56 tahun 2021 terhadap eksistensi pencipta lagu}

Eksistensi merupakan keberadaan yang mengandung unsur bertahan secara terusmenerus berjalan secara lancar, eksistensi pencipta lagu dapat terlihat dari aktivitas karya cipta secara terus-menerus berjalan dan ada di tengah masyarakat. Ciptaan menurut PP No. 56 tahun 2021 adalah setiap karya cipta bidang seni yang dihasilkan atas keterampilan, keahlian serta kemampuan dan diekspresikan dalam bentuk nyata. Ciptaan tersebut berupa lagu maupun musik yang dieskpresikan pencipta lagu secara terus menerus dan ada di tengah masyarakat.

PP No. 56 tahun 2021 telah memberi dampak terhadap eksistensi pencipta lagu. Perlindungan hak ekonomi memberi semangat 


\section{Sri Wahyuni Muhtar, Faisal Faisal \\ Eksistensi Pencipta Lagu Setelah Peraturan Pemerintah Nomor 56 Tahun 2021 Disahkan}

bagi pencipta lagu agar tetap eksis dalam berkarya. Adanya perlindungan hukum yang terkandung juga dalam pasal 9 ayat 1 UU nomor 28 tahun 2014 tentang hak cipta menyebutkan hak ekonomi pencipta atau pemegang hak terdapat pada penerbitan karya, penggandaan, pengaransemenan, pengadaptasian, pertunjukan dan lain sebagainya.

Selain dampak produktivitas yang terjadi juga adanya dampak psikologis bagi pencipta lagu lebih nyaman dan tenang memproduksi lagu sebab merasa percaya tidak akan dirugikan karena adanya PP No.56 tahun 2021. Annisa Theresia EEP atau Teri sebagai artis penyanyi dan pencipta lagu telah bergabung sebagai anggota LMK WAMI pada tanggal 26 April 2021 dalam kesempatan webinar Kenali HakHak Kekayaan Intelektual Komposer menyatakan dampak PP No. 56 tahun 2021 terhadap eksistensi pencipta lagu sebagai penyemangat dalam menciptakan karya-karya yang bermutu dan berkualitas, juga memberi kesempatan para pencipta lagu berkolaborasi menghasilkan karya cipta yang menarik bagi masyarakat.

Pentingnya mengetahui hak pencipta lagu juga dikemukakan oleh Ikke Nurjanah pada tanggal 22 Juli 2021 yang diselenggarakan oleh LMK PAPPRI (Persatuan Artis Penyanyi, Pencipta Lagu, dan Pemusik Republik Indonesia) dalam pro kontra PP No. 56 tahun 2021, ketika mengetahui adanya perlindungan hukum para pencipta lagu mendapatkan harapan hidup dari aspek ekonomi. Hasil wawancara tim peneliti kepada Muhlis sebagai pencipta lagu di Makassar mengungkapkan dampak PP No. 56 tahun 2021 terhadap eksistensi pencipta lagu sebagai rencana strategi berkarya masa depan agar hak ekonomi dapat diterima secara maksimal. Industri musik yang ada di Makassar saat ini telah memanfaatkan berbagai platform untuk tetap eksis. Karya cipta berbagai genre serta kolaborasi pelaku pertunjukan dimaksimalkan untuk menarik perhatian masyarakat.

Dokumentasi gambar di atas adalah aktivitas anggota PAPPRI Sulawesi Selatan yang mengadakan pelantikan pengurus disertai pertunjukan penampilan anggota PAPPRI pada tanggal 22 Agustus 2021. PAPPRI juga telah mengadakan webinar Implementasi Peraturan Pemerintah No. 56 Tahun 2021 Terkait Tata Cara dan Mekanisme Pengumpulan Royalti Lagu, setelah kegiatan webinar tersebut para anggota mengagendakan program-program untuk memajukan pelaku musik di Sulawesi Selatan. Menjawab rumusan masalah penelitian mengenai dampak aturan tersebut disahkan yaitu sebagai acuan yang melahirkan antusiasme dan memberi ruang bekerjasama berbagai pihak pelaku musik dalam memproduksi karya cipta yang berkualitas khususnya pada industri musik Sulawesi Selatan.

\section{Pembahasan}

\section{Respons pencipta lagu setelah PP No. 56 tahun 2021 disahkan}

Terlihat pada hasil penelitian bahwa respons pencipta lagu setelah PP No. 56 tahun 2021 disahkan yaitu mendaftarkan diri menjadi anggota LMK agar mudah mendapatkan royalti. Royalti didefenisikan oleh Zefanya (2020) terdapat dalam peraturan sebelumnya yaitu UU nomor 28 tahun 2014 bahwa pada pasal 1 ayat 22 UU hak cipta royalti adalah imbalan atas pemanfaatan hak ekonomi suatu ciptaan lagu yang diterima oleh pencipta atau pemegang hak cipta lagu, defenisi royalti tersebut juga terkandung dalam PP No. 56 tahun 2021 pasal 1 ayat 1. Hak ekonomi yang didapatkan dari pemungutan royalti harus melalui suatu LMK pencipta seperti KCI, WAMI atau RAI.

(Husnun et al., n.d.) menyatakan bahwa PP nomor 56 tahun 2021 telah mengoptimalkan fungsi dari pengelolaan royalti dari pemanfaatan karya cipta lagu. Melalui LMK para pencipta lagu dapat menerima hak ekonominya, tertuang juga dalam pasal 1 ayat 22 UU hak cipta bahwa LMK (Lembaga Manajemen Kolektif) memiliki wewenang untuk mengelola dan mendistribusikan royalti selanjutnya pada PP nomor 56 tahun 2021 tercantum di pasal 14 ayat ayat 1 bahwa royalti yang telah dihimpun oleh LMKN didistribusikan kepada pencipta lagu yang telah menjadi anggota LMK. Berdasarkan hal tersebut maka para pencipta lagu mendaftarkan diri sebagai anggota LMK agar dapat menerima royalti dari pemanfaatan karya cipta yang bersifat komersil.

Respons selanjutnya adalah pencipta lagu mendaftarkan karya ciptaan secara sah ke Direktorat Jenderal Kekayaan Intelektual (DJKI) Kemenkumham untuk melindungi karya secara hukum agar tidak diklaim orang lain terkait kepemilikian hak cipta dari suatu karya lagu. Hal tersebut juga menjadi himbauan dari Dirjen Kekayaan Intelektual Dr. Freddy Haris, ACCS bagi para pencipta lagu agar mendaftarkan karya ciptanya pada press conference PP nomor 56 
tahun 2021 tentang pengelolaan royalti hak cipta lagu pada tanggal 9 April 2021 dari youtube DJKI Kemenkumham. Pencatatan hak cipta juga diatur dalam pasal 7 PP No.56 tahun 2021 mengenai pusat data lagu dan/atau musik paling sedikit memuat informasi mengenai hak cipta seperti salah satunya adalah kode E-Hak Cipta Direktorat Jenderal. Berangkat dari hal tersebut maka pencipta lagu mendaftarkan ciptaan secara resmi melalui laman e-hakcipta.dgip.go.id.

Pada hasil penelitian juga diungkapkan adanya respons pencipta lagu tidak ingin mendaftarkan diri sebagai anggota LMK karena adanya kekhawatiran karya ciptaan akan terbatas dinikmati masyarakat dan dapat merugikan eksistensi lagu yang telah dibuat. Hal tersebut diungkapkan dalam komentar dari seorang pencipta lagu saat sosialisasi PP nomor 56 tahun 2021 di Instagram. Webinar terkait pro kontra PP No. 56 tahun 2021 sudah digelar oleh DJKI Kemenkumham, LMK-LKM serta perguruan tinggi yang memiliki fakultas hukum seperti Universitas Hasanuddin dan Universitas Katolik Indonesia Atmajaya.

Berbagai respons pencipta lagu setelah PP No.56 tahun 2021 disahkan merupakan respons terhadap pemerintah yang telah memberi perlindungan hukum bagi karya cipta lagu, PP No.56 tahun 2021 menarik banyak perhatian para pencipta lagu. Hasil pengamatan dan dokumentasi di lapangan menunjukkan banyaknya respons positif dan senang adanya payung hukum yang melindungi hak-hak para pencipta lagu walaupun masih ada beberapa pencipta lagu yang memilih untuk tidak menerima hak ekonomi melalui LMK dengan alasan kekhawatiran karya ciptaan yang dikomsumsi secara terbatas. PP Nomor 56 tahun 2021 mengatur banyak hal terkait pengelolaan royalti musik, pemerintah telah melegalkan hal yang sudah ditunggu oleh para pelaku musik. Adanya aturan ini akan membantu pencipta lagu, ahli waris pemilik hak cipta, dan pemilik hak terkait mendapatkan hak ekonomi. Namun pencipta lagu berharap aturan dapat diaktualisasikan secara maksimal karena pengelolaan royalti saat ini masih membutuhkan niat baik para pengguna karya cipta yang memanfaatkan lagu dan/musik secara komersil agar mendaftarkan diri secara resmi dan menyelesaikan pembayaran royalti sesuai ketentuan yang berlaku. Sebagai contoh tarif royalti dari data LMKN mulai dari hotel dan fasilitas hotel jumlah kamar lebih dari 200 yaitu sebesar Rp. 12.000.000,- , restoran dan kafe untuk hak pencipta dihitung Rp. 60.000,-/kursi, radio non komersil dihitung lumsum bagi hak pencipta Rp 1.000.000,- per tahun, televisi lokal non komersial dihitung lumsum bagi hak pencipta Rp. 6.000.000,- pertahun, pusat rekreasi jika tidak menggunakan tiket dihitung lumsum Rp. 6.000.000,- pertahun, serta karaoke keluarga sebesar Rp. 12.000,- per kamar/hari.

Pada pasal 14 PP No.56 tahun 2021 tercantum bahwa royalti dihimpun oleh LMKN (Lembaga Manajemen Kolektif Nasional) berdasarkan laporan penggunaan data lagu yang ada di SILM (Sistem Informasi Lagu). Dari data lapangan informasi mengenai SILM masih dalam proses pembangunan, dari informasi tersebut diharapkan pencipta lagu dapat mempersiapkan data ciptaan karya lagu yang dimasukkan dalam SILM.

\section{Dampak PP No.56 tahun 2021 terhadap eksistensi pencipta lagu}

LMK WAMI pada tanggal 24 September 2021 telah memposting informasi laporan penjualan produk musik di Amerika Serikat melalui Instagram, fenomena RIAA (Recording Industry Association of America) untuk semester pertama tahun $2021,84 \%$ pendapatan berasal dari streaming mencakup layanan iklan, layanan berbayar, lisensi musik di Facebook, aplikasi kebugaran, radio digital dan costumized. Dari data $84 \%$ tersebut terdapat $3 / 4$ pendapatan streaming yang berasal dari layanan berbayar. Fenomena tersebut menjadi motivasi bagi pencipta lagu untuk mempublikasi karya cipta dan mendaftarkan link Youtube ke LMK pencipta.

Selain hak ekonomi, hak moral juga dapat diketahui oleh pencipta lagu seperti yang diungkapkan WIPO dalam penelitian (Sinaga, 2020) yaitu hak publikasi, hak mengklaim dan hak integritas. Perlunya kesadaran hukum bagi pencipta lagu akan membantu pengelolaan dan pendistribusian royalti tepat sasaran. Salah satu manfaat penelitian ini bukan hanya sebagai media sosialisasi sadar hukum bagi pencipta lagu tetapi juga sosialisasi kesadaran membayar royalti bagi pengguna ciptaan karya yang memanfaatkan secara komersil, (Regina Widyaningtyas \& Haura Zahra, n.d.) mengemukakan dalam pasal 113 ayat 2 dan 3 UU hak cipta yaitu bagi pelanggar aturan royalti mendapatkan sanksi pidana penjara paling lama 3 (tiga) tahun dan/atau denda paling banyak Rp 500.000.000,00 (lima ratus juta rupiah). Maka 


\section{Sri Wahyuni Muhtar, Faisal Faisal \\ Eksistensi Pencipta Lagu Setelah Peraturan Pemerintah Nomor 56 Tahun 2021 Disahkan}

diharapkan bagi pengguna musik dan/atau lagu secara komersil dapat mendaftarkan data karya yang diputar atau diperdengarkan pada hotel, restoran, kafe, radio, televisi, pusat rekreasi, maupun usaha karaoke.

Disahkannya PP No. 56 tahun 2021 memberikan dampak positif bagi pencipta lagu yaitu eksistensi identitas sebagai hak moral terpenuhi, pengelolaan royalti membutuhkan data dari pencipta lagu dari sebuah karya sehingga setiap lagu harus jelas nama penciptanya. Maka pencipta lagu akan eksis dari hak publikasi. PP nomor 56 tahun 2021 juga memberi dampak produktivitas pencipta lagu semakin eksis, perlindungan hak ekonomi akan mendapatkan royalti memberi semangat bagi pencipta lagu untuk menciptakan karya yang berkualitas dan terus menerus berkarya. Berkarya secara sendiri-sendiri maupun berkelompok dilakukan untuk memenuhi kebutuhan "pasar" industri musik.

Dampak selanjutnya selain eksistensi nama pencipta dan eksistensi karya, dalam penelitian menemukan bahwa adanya dampak peningkatan karir dalam dunia industri musik. Ketika dampak publikasi nama pencipta diketahui masyarakat luas tentu nama pencipta yang melekat pada karya lagu juga diketahui oleh berbagai pihak yang akan menawarkan kerjasama yang menguntungkan di industri musik dalam skala nasional maupun internasional.

Fenomena pengesahan PP No.56 tahun 2021 telah memberi ruang kerjasama dan kolaboratif secara positif bagi para pencipta, seperti yang diungkapkan (Krzyżaniak, 2021) Pembuatan musik adalah kegiatan kompleks yang dilakukan secara kolaboratif oleh banyak orang. Kemudian artis penyanyi maupun musisi terdorong untuk menghasilkan karya yang berkualitas dan bermutu setelah adanya pengesahan PP No.56 tahun 2021. Untuk menghasilkan karya musik yang bermutu, pencipta lagu memiliki teknik masing-masing. Salah satunya adalah eksplorasi teknik komposisi musik klasik kontemporer. (Azizol, 2017). Perlindungan hak ekonomi telah dijamin secara hukum. Data lapangan dari beberapa LMK mengutip PP No.56 tahun 2021 sebagai keberanian dan kepercayaan diri untuk memenuhi hak pencipta lagu. Para pencipta karya juga yakin secara finansial bahwa profesi tersebut dapat diandalkan sebagai profesi yang menjanjikan.
Eksistensi pencipta lagu setelah PP No.56 disahkan telah membangkitkan semangat berkarya anak bangsa Indonesia, penghargaan secara ekonomi yang diterima oleh pencipta maupun hak waris memberi "angin segar" di industri musik Indonesia. Pencipta lagu berharap selanjutnya pendistribusian royalti dapat tersampaikan secara terbuka dan berkelanjutan, nyata dalam penerimaan hak ekonomi serta mendapatkan besaran rupiah yang adil dan sesuai aturan yang berlaku.

\section{KESIMPULAN}

Respons secara positif pencipta lagu setelah PP Nomor 56 tahun 2021 disahkan melalui pendaftaran diri dan karya di LMK hak pencipta, serta mendaftarkan karya secara online di DJKI Kemenkumham. Namun ada juga pencipta lagu yang belum memberi respons mendaftarkan karya secara kelembagaan karena kekhawatiran ciptaan akan dikonsumsi secara terbatas sehingga memberikan kerugian publikasi bagi pencipta. Selanjutnya, dampak PP Nomor 56 tahun 2021 terhadap eksistensi pencipta lagu membuat pencipta lebih produktif menghasilkan karya secara berkala, pembuatan karya menjadi lebih berkualitas dan bermutu di dunia industri musik, serta hak publikasi pencipta lagu eksis di masyarakat dan pihak pemanfaatan karya berskala nasional dan internasional.

\section{DAFTAR PUSTAKA}

Adi, Isbandi Rukminto (2013). Kesejahteraan Sosial, Depok : Rajawali Pres.

Azizol, A. (2017). Sonic exploration of alto recorder for Nadi Bumi: Applied research in contemporary classical music composition. Malaysian Music Journal, 6(2).https://doi.org/10.37134/mjm.vol6.2.4 .2017

Hasanah, H. (2017). Teknik-Teknik Observasi (Sebuah Alternatif Metode Pengumpulan Data Kualitatif Ilmu-ilmu Sosial). AtTaqaddum, $\quad 8 \quad$ (1). https://doi.org/10.21580/at.v8i1.1163

Husnun, A., Hafiz, M., Ramadhani, R., \& Balerina, W. H. (n.d.). Padjadjaran Law Review.

https://www.kompas.com/tren/read/2021/0 $4 / 09 / 1150$

Ikram, A. D. (2020). Eksistensi Grup Dj Vibetronic Sebagai Penyaji Electronic Dance Music di Kota Surabaya. Virtuoso: Jurnal Pengkajian Dan Penciptaan Musik, 
2(1). https://doi.org/10.26740/vt.v2n1.p2833

Krzyżaniak, M. (2021). Musical robot swarms, timing, and equilibria. Journal of New Music Research, 50(3). https://doi.org/10.1080/09298215.2021.19 10313

Muhtar, S. W. (2021). Penyajian Musik Tradisional Gandrang dalam Prosesi Akkorongtigi. Nuansa Journal of Arts and Design, $4(2)$. https://doi.org/10.26858/njad.v4i2.17291

Regina Widyaningtyas, K., \& Haura Zahra, T. (n.d.). Padjadjaran Law Review Tinjauan Hak Cipta Terhadap Kewajiban Pembayaran Royalti Pemutaran Lagu di Sektor Usaha Layanan Publik.
Sinaga, E. J. (2020). Pengelolaan Royalti atas Pengumuman Karya Cipta Lagu. Jurnal Ilmiah Kebijakan Hukum, 14(3). https://doi.org/10.30641/kebijakan.2020.v1 4.553-578

Somawati, A. V., Adnyana, K. S., Darmawan, I. P. A., Dewi, N. P. D. U., Untara, I. M. G. S., Suadnyana, I. B. P. E., \& Paramita, I. B. G. (2020). Bali vs Covid-19: Book Chapters. Nilacakra, 1.

Sugiyono. (2013). Metode Penelitian Pendidikan Pendekatan Kuantitaif, Kualitatif, dan R\&D. $\quad$ https://doi.org/10.1. Metode Penelitian Pendidikan Pendekatan Kuantitaif, Kualitatif, Dan R\&D. 